\title{
Repair strategies in labial dissimilation: Diminutive formations in Xitsonga
}

\author{
Seunghun J. Lee \\ English, Central Connecticut State University, New Britain, CT, USA \\ E-mail: juliolee@gmail.com \\ Clementinah Burheni \\ University of Venda, Thohoyandou, Limpopo Province, South Africa \\ E-mail: cburheni@gmail.com
}

\begin{abstract}
This paper presents phonological processes in Xitsonga diminutives. The round vowels $/ \mathrm{u} / \mathrm{and} / \mathrm{o} /$ are changed into the glide [w] to avoid vowel hiatus. When the glide [w] is preceded by labial consonants, then other processes occur: either the labial nasal $[\mathrm{m}]$ corresponds to a velar, or the glide $[\mathrm{w}]$ deletes when preceded by labial obstruents. The seemingly disjunctive processes are argued to be responses to the OCP-LABIAL constraint in which adjacent segments with [labial] are prohibited. A rule-based analysis and a constraint-based (Optimality Theory) analysis are presented to discuss these processes. Data with affrication is introduced as an alternative repair strategy, but is not included in the formal analysis, which focuses on labial dissimilation.
\end{abstract}

Keywords: Xitsonga, diminutives, labial dissimilation, Optimality Theory, OCP

\section{Introduction}

In Xitsonga diminutive formation, the juncture between the root and the suffix undergoes various phonological processes: glide formation, velarisation and vowel deletion. We argue that these seemingly disjointed processes are results of repair strategies that apply in order to avoid a sequence of labial sounds.

In (1), the template for the Xitsonga diminutive is shown (Baumbach 1987:148-157, Ziervogel $1967: 216-234)$. The root noun is immediately preceded by the class (CL)7/8 prefix and followed by -ana. When the root noun is preceded by a prefix, the CL7/8 prefix substitutes the original prefix, as in (1a). When the root noun is monosyllabic or has the CL7 prefix, the diminutive CL7/8 prefix is added to the stem, as in (1b). The acute accent marks high $(\mathrm{H})$ tone and the grave accent marks surface low (L) tone. 
(1) The circumfix template for the Xitsonga diminutive xi-Root.Noun-ana [ [ji-] 'CL7-a small Root Noun' swi-Root.Noun-ana [si-] 'CL8-small Root Noun(s)'

(singular or count nouns) (plurals or mass nouns)

a. Substitution of the CL7/8 prefix

[mà-sàngù] 'sleeping mats' [tì-hòmú] 'cattle'

b. Addition of the CL7/8 prefix [sì-sàngw-ànà] 'small sleeping mats'

[sì-hònw-áná] 'small cattle'
[mù-ṇù] 'a person'
[ [̂̉-mùnw-ànà] 'a small person'
[jî-nkwà] 'bread'

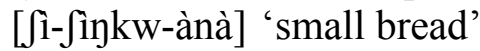

While there are no changes between the prefix $x i$ - and the root noun, phonological processes do occur between the root noun and the suffix -ana: (i) the root-final vowel is deleted due to vowel hiatus, as in (2a-c); (ii) the root-final vowel becomes a glide, as in (2d), or (iii) the root nasal is velarised, as in (2e).

(2) Phonological processes occurring between the root noun and-ana

\begin{tabular}{|c|c|c|c|c|}
\hline & Root noun & Diminutive & '(a) small ...' & Sound change \\
\hline a. & [sáká] & [Jî-sák-áná] & grain bag & Vowel Deletion \\
\hline b. & [séké] & [sì̀-sék-áná] & sand & Vowel Deletion \\
\hline c. & [mbútí] & 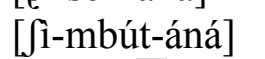 & goat & Vowel Deletion \\
\hline d. & [nłókó] & 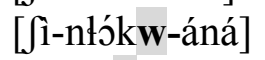 & head & Glide Formation \\
\hline e. & [nsímú] & 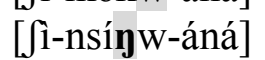 & field & Velarisation \\
\hline
\end{tabular}

When the root-final vowel is unrounded (/a, e, i/), the vowel deletes before the diminutive suffix. The round vowels $/ \mathrm{u} /$ and $/ \mathrm{o} /$ become the labial glide $[\mathrm{w}]$. When a consonant immediately preceding the round vowels is a labial, velarisation or affrication is triggered (indicated by the dark-shaded cells in (3)). One of the aims of this paper is to present a comprehensive data set of all the phonological patterns in each cell in (3).

(3) Phonological patterns in Xitsonga diminutives

\begin{tabular}{|c|c|c|c|c|c|}
\hline /...CV-ana/ V= & $/ \mathrm{u} /$ & /o/ & $/ \mathrm{a} /$ & /e/ & /i/ \\
\hline Labials & $\ldots$ C-ana ${ }^{+}$ & C-ana ${ }^{+}$ & ...C-ana & ...C-ana & ...C-ana \\
\hline$[\mathrm{m}]$ & ...nw-ana & ...nw-ana & & & \\
\hline Coronals & ...CW-ana & ...CW-ana & ...C-ana & ...C-ana ${ }^{+}$ & ...C-ana \\
\hline Dorsals & ...CW-ana & ...Cw-ana & ...C-ana & ...C-ana & ...C-ana \\
\hline
\end{tabular}

( ${ }^{+}$Some consonants occasionally become affricates; this is in addition to vowel deletion.)

Vowel hiatus motivates the deletion of (unrounded) vowels. Velarisation of the root consonant $/ \mathrm{m} /$ to $[\mathrm{y}]$ and the round-vowel deletion after $/ \mathrm{f} /$ and other labial sounds are argued to be the result of labial dissimilation. Phonological processes in diminutive formation are found in other southern Bantu languages as well. In Northern Sotho, when the stem-final vowel is a back vowel ([o] or [u]), it becomes the labial glide [w] (cf. Kotzé and Zerbian 2008:12), just as in Xitsonga. In this paper, a rule-based analysis and a constraint-based analysis (the latter in terms 
of Optimality Theory (OT)) will be discussed in order to explain various phonological processes that occur in the diminutive formation in Xitsonga.

In section 2, facts about Xitsonga and the data collection methods are presented. This will be followed by a data-oriented section that aims to provide a comprehensive picture of phonological patterns of Xitsonga diminutive formation. The analyses in section 4 argue that phonological processes found in Xitsonga diminutives are repair strategies in labial dissimilation. In section 5, a short discussion about the affrication data will be presented.

\section{Background and data collection}

Xitsonga (also called Changana or Rhonga) is spoken by about 2 million people in South Africa, Zimbabwe, Mozambique and Lesotho. In South Africa, Xitsonga is one of the 11 official languages and is spoken mainly in the northeastern part of the Limpopo province. Most Xitsonga speakers know English, but many of them use only Xitsonga in everyday life. It is also possible to receive education up to a tertiary level in the language. Xitsonga speakers share the linguistic sphere with Tshivenda and Northern Sotho speakers. The Xitsonga variety reported in this paper is the Xiluleke dialect spoken in the Mhinga area of Limpopo, South Africa.

Xitsonga consonants are shown in (4). The right consonant in each pair is laryngealised - either aspirated or breathy voiced. The major difference of this chart from previous work is the absence of the palatal fricative $[\mathrm{x}] .^{1}$ The relevant consonants for this paper are the labial consonants as shown in the dark-bordered box.

(4) Xitsonga consonant inventory (adapted from Baumbach 1987)

\begin{tabular}{|c|c|c|c|c|c|c|c|c|c|c|c|c|c|}
\hline & \multicolumn{3}{|c|}{ labial } & \multicolumn{4}{|c|}{ alveolar } & \multicolumn{2}{|c|}{ palatal } & \multicolumn{3}{|c|}{ velar } & glottal \\
\hline Stops & $\mathrm{p} \quad \mathrm{p}^{\mathrm{h}}$ & $\mathrm{b}$ & & $\mathrm{t}$ & $\mathrm{t}^{\mathrm{h}}$ & $\mathrm{d}$ & & & & $\mathrm{k}$ & g & & \\
\hline Prenasalised & & $\mathrm{m}_{\mathrm{b}}$ & (m) $b$ & & & & (n) $\mathrm{d}$ & & & $\mathrm{k}^{\mathrm{h}}$ & ${ }^{\mathrm{g}} \mathrm{g}$ & $(\mathrm{g}) \ddot{\mathrm{g}}$ & \\
\hline Fricatives & $\mathrm{f}$ & $\beta$ & $\mathrm{V}$ & $\mathrm{s}$ & th & $\mathrm{z}$ & $\mathrm{db}$ & $\int \quad s$ & & & & & h \\
\hline Affricates & $\mathrm{pf} \mathrm{pf}^{\mathrm{h}}$ & bv & mby & ts & $t^{h}$ & dz & ${ }^{\mathrm{n}} \mathrm{d}$ & ty $\mathfrak{y}^{h}$ & ds ${ }^{n} \ddot{d s}$ & & & & \\
\hline Nasals & & $\mathrm{m}$ & m & & & $\mathrm{n}$ & n & & $\mathrm{n}$ & & $\eta$ & $\ddot{\mathrm{y}}$ & \\
\hline Lateral & & & & 1 & & 1 & & & & & & & \\
\hline Rhotic & & & & & & $\mathrm{r}$ & $r$ & & & & & & \\
\hline Glides & & W & & & & & & & $\mathrm{j}$ & & & & \\
\hline
\end{tabular}

The data collection method was aided by a Xitsonga noun corpus built from a Xitsonga dictionary (Cuenod 1967). The Microsoft Access database consists of 1582 nouns, which the second author identified as being in active use in her own speech. Where there were any discrepancies between the second author's pronunciations and those of Cuenod, these were resolved by following the second author's speech form. A script that creates a reverse string list

\footnotetext{
${ }^{1}$ The status of the velar fricative [x] has been cross-examined with native speakers of Xitsonga. In Baumbach (1987), a single ideophone hhatawu [xatawu] ('of keeping very quiet') is listed. Linguistically trained speakers of Xitsonga were unable to identify a single word containing the $[\mathrm{x}]$ sound in the language. Lee (2009) confirmed that his consonant chart was directly taken from Baumbach (1987) prior to any consultation with Xitsonga speakers. We conclude that the variety of Xitsonga in this paper does not have the velar fricative [x].
} 
sorted nouns from the last character in the orthography. ${ }^{2}$ Any items that we were unsure about were double-checked by the second author with other Xitsonga native speakers.

\section{Diminutive formations in Xitsonga: Data}

Various phonological processes in Xitsonga diminutives have been reported in previous studies (cf. Baumbach 1987:148-157, Ziervogel 1967:216-234), but the reported paradigm has gaps in terms of phonological environments. This section aims to fill these gaps. The root-final unrounded vowels /a, e, i/ undergo vowel deletion in most environments. As such, this section will only report on roots that end with the round vowels $/ \mathrm{o} /$ and $/ \mathrm{u} /$.

\subsection{Glide formation}

The root-final round vowels $/ \mathrm{o} /$ and $/ \mathrm{u} /$ correspond to the labial glide $[\mathrm{w}]$ in diminutive forms. The consonant preceding the root-final vowel can be an alveolar, a palatal, a velar or a glottal. In (5), the root-final vowel is $/ \mathrm{o} /$. The collected data contains accidental gaps because no roots have the following /-Co/ forms, in which the consonant $/ \mathrm{C} /$ is $\left[\mathrm{s}, \mathrm{y}, \mathfrak{t}, \mathrm{d}_{3}\right]$ or breathy voiced.

(5) Non-labial consonants $+/ \mathrm{o} /$ before the diminutive suffix -ana

\begin{tabular}{|c|c|c|c|c|}
\hline & Root noun & Diminutive & '(a) small ...' & \\
\hline \multirow[t]{5}{*}{$\begin{array}{ll}\text { a. } & {[\mathrm{t}]}\end{array}$} & [pótó] & [Jî-pótw-áná] & pot & Alveolars \\
\hline & [ $\int i p^{h}$ àtò] & [ $\int \hat{1}-p^{h}$ àtw-ànà $]$ & totem & \\
\hline & [tòtó] & [ [î-tótw-áná] & animal waste & \\
\hline & [k ótò] & [ $\int \hat{1}-\mathrm{k}^{\mathrm{h} o ́ t w-a ́ n a ́] ~}$ & court & \\
\hline & [sóntò] & [ [̂̀-sóntw-áná] & Sunday & \\
\hline \multirow[t]{3}{*}{$\begin{array}{ll}\text { b. } & {[\mathrm{d}]}\end{array}$} & [bódó] & [Jî-bódw-áná] & hole & \\
\hline & [كîgòdó] & [ ĵi-gòdw-áná] & tree stump & \\
\hline & [ $\left[\mathrm{ik}^{\mathrm{h}} \mathrm{òdò}\right]$ & [ $\int \mathrm{i}-\mathrm{k}^{\mathrm{h}} \mathrm{òdw}$-ànà $]$ & a useless person & \\
\hline \multirow[t]{5}{*}{$\begin{array}{ll}\text { c. } & {[\mathrm{n}]}\end{array}$} & [t $\mathrm{t}^{\mathrm{h}}$ ònónó] & 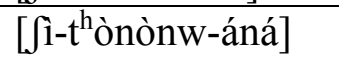 & cricket & \\
\hline & [mànò] & [sì-mànw-ànà] & senses & \\
\hline & [ Jipànó] & [ [̂i-pánw-áná] & team & \\
\hline & [ménó] & [sì̀-ménw-áná] & teeth & \\
\hline & [tínó] & [ [î-tínw-áná] & a tooth & \\
\hline \multirow[t]{6}{*}{$\begin{array}{ll}\text { d. } & {[1]}\end{array}$} & [Jitóló] & 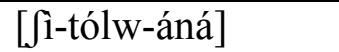 & store & \\
\hline & [ndòlòlò] & [ $\int 1$-ndòlòlw-ànà] & pupil of an eye & \\
\hline & [ndzéló] & [ [̂̀-ndzélw-áná] & wooden bow & \\
\hline & [k òlòk ${ }^{\mathrm{h}}$ òlò] & 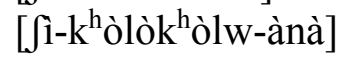 & larynx & \\
\hline & [nkòlò] & [ [î-nkòlw-ànà] & neck & \\
\hline & [k òk ò̀lò] & [ $\int \hat{1}-\mathrm{k}^{\mathrm{h}} \mathrm{òk}^{\mathrm{h}} \mathrm{òlw}$-ànà $]$ & castle & \\
\hline \multirow[t]{4}{*}{ e. $[\mathrm{r}]$} & [nòmbòrò] & [ jî-nòmbòrw-ànà] & number & \\
\hline & [k òlòrò] & [ $\int \mathrm{i}-\mathrm{k}^{\mathrm{h}}$ òlòrw-ànà $]$ & collar & \\
\hline & [tònòrò] & [ [1-tònòrw-ànà] & snoring & \\
\hline & [mùgéró] & [ [î-gérw-ánà] & canal & \\
\hline $\begin{array}{ll}\text { f. } & {[\mathrm{s}]}\end{array}$ & [k ósò] & [ $\int 1-k^{\text {hósw-ánà }]}$ & coarse & \\
\hline
\end{tabular}

\footnotetext{
${ }^{2}$ We thank James V. Bruno for creating and sharing the Excel script.
} 


\begin{tabular}{|c|c|c|c|c|}
\hline g. [ts $]$ & $\begin{array}{l}\text { [bdzàtsò] } \\
{\left[\mathrm{k}^{\text {hòtsò] }}\right.} \\
\text { [Jitsòtsò }]\end{array}$ & 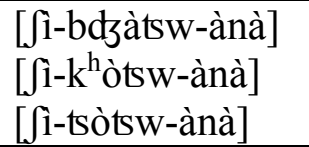 & $\begin{array}{l}\text { boat } \\
\text { prison } \\
\text { locust }\end{array}$ & \\
\hline $\begin{array}{ll}\text { h. } & {[\mathrm{dz}]}\end{array}$ & $\begin{array}{l}\text { [rìmóndzò] } \\
\text { [sóndzó] } \\
\text { [màßónczó] }\end{array}$ & 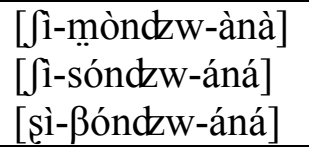 & $\begin{array}{l}\text { horn } \\
\text { cow's leg } \\
\text { jealousy }\end{array}$ & \\
\hline i. $\quad[J]$ & [mìjó] & 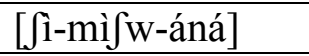 & morning & Palatals \\
\hline j. $[\mathrm{n}]$ & [mì̀nàkànò] & [sì-ànàkàjw-ànà] & thoughts & \\
\hline k. $\quad[\mathrm{j}]$ & [mùgàjò] & [sì-gàjw-ànà] & mealie meal & \\
\hline 1. $\quad[\mathrm{k}]$ & $\begin{array}{l}{[\beta \text { ókó }]} \\
\text { [ckókò }] \\
{\left[\mathfrak{t g}^{\text {hókò }]}\right.} \\
{[\text { tlilókò }]}\end{array}$ & 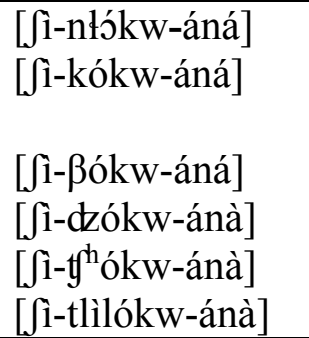 & $\begin{array}{l}\text { head } \\
\text { hard part after } \\
\text { cooking porridge } \\
\text { hand } \\
\text { yoke } \\
\text { chalk } \\
\text { clock }\end{array}$ & Velars \\
\hline m. $[\mathrm{g}]$ & [gògógò] & [ [î-gògógw-ánà] & empty tin & \\
\hline n. $[\mathrm{h}]$ & $\begin{array}{l}\text { [ntòfò] } \\
\text { [nḍófò ] } \\
\text { [rìntìfò] } \\
\text { [mìrófó] }\end{array}$ & 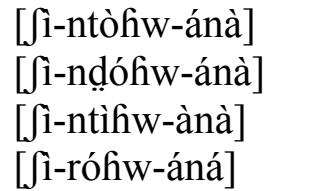 & $\begin{array}{l}\text { monkey } \\
\text { maize seeds } \\
\text { finger } \\
\text { vegetable }\end{array}$ & Glottals \\
\hline
\end{tabular}

In (6), the root-final vowel is $/ \mathrm{u} /$, which becomes the glide $[\mathrm{w}]$ in the diminutive. Three accidental gaps are found in the $/-\mathrm{Cu} /$ forms, in which $/ \mathrm{C} /$ is $[\mathrm{s}, \mathrm{y}, \mathrm{d}]$ or breathy voiced.

(6) Non-labial consonants $+/ \mathrm{u} /$ before the diminutive suffix -ana

\begin{tabular}{|c|c|c|c|c|}
\hline & Root noun & Diminutive & '(a) small ...' & \\
\hline \multirow[t]{2}{*}{$\begin{array}{ll}\text { a. } & {[\mathrm{t}]}\end{array}$} & [pátú] & [Jì-pátw-áná] & path & Alveolars \\
\hline & [ $\left.\int \mathrm{ik} \mathrm{k}^{\mathrm{h}} \mathrm{u} t \mathrm{u}\right]$ & 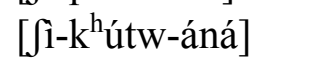 & trap & \\
\hline \multirow[t]{3}{*}{$\begin{array}{ll}\text { b. } & {[\mathrm{n}]}\end{array}$} & [czànù] & [șì-ckànw-ànà] & sense & \\
\hline & [nttánù] & [ Jî-ntlánw-áná] & 50 cent & \\
\hline & [Đkánú] & 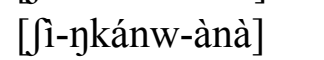 & stubborn & \\
\hline \multirow{6}{*}{ c. $[1]$} & [Jîtúlú] & [Jî-túlw-áná] & chair & \\
\hline & [dùlù] & [Jî-dùlw-áná] & hut for storing harvest & \\
\hline & [ $\beta$ ùlù $\beta$ ùlù] & 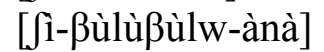 & tadpole & \\
\hline & [mpàlú] & [Jî-mpálw-áná] & material for cloth & \\
\hline & [mbilú] & [ jî-mbílw-áná] & heart & \\
\hline & [Sikálú] & [ jî-kàlw-áná] & measuring things & \\
\hline \multirow[t]{2}{*}{$\begin{array}{ll}\text { d. } & {[\mathrm{r}]}\end{array}$} & 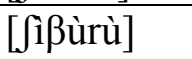 & [ ĵi-ßùrw-ànà $]$ & non-initiator & \\
\hline & [màtlúrú] & [șì-tlúrw-áná] & bullets & \\
\hline $\begin{array}{ll}\text { e. } & {[\mathrm{s}]}\end{array}$ & [Jìpésú] & $\begin{array}{l}\text { [Jì-pésw-áná] } \\
\text { [sì-khúsw-áná] }\end{array}$ & back part of a chicken & \\
\hline f. $\quad[]$ & [màfùfù] & [sì-fùfw-ànà] & eagerness & Palatals \\
\hline g. [n] & [múnú] & [sì-múnw-áná] & salt & \\
\hline h. [y] & [k hàntfú] & [ $\int \mathrm{i}-\mathrm{k}^{\mathrm{h}}$ àntfw-áná] & long garments & \\
\hline i. $[\mathrm{d}]$ & [gwàdzú] & [ jì-gwàdzw-áná] & tick mark & \\
\hline
\end{tabular}




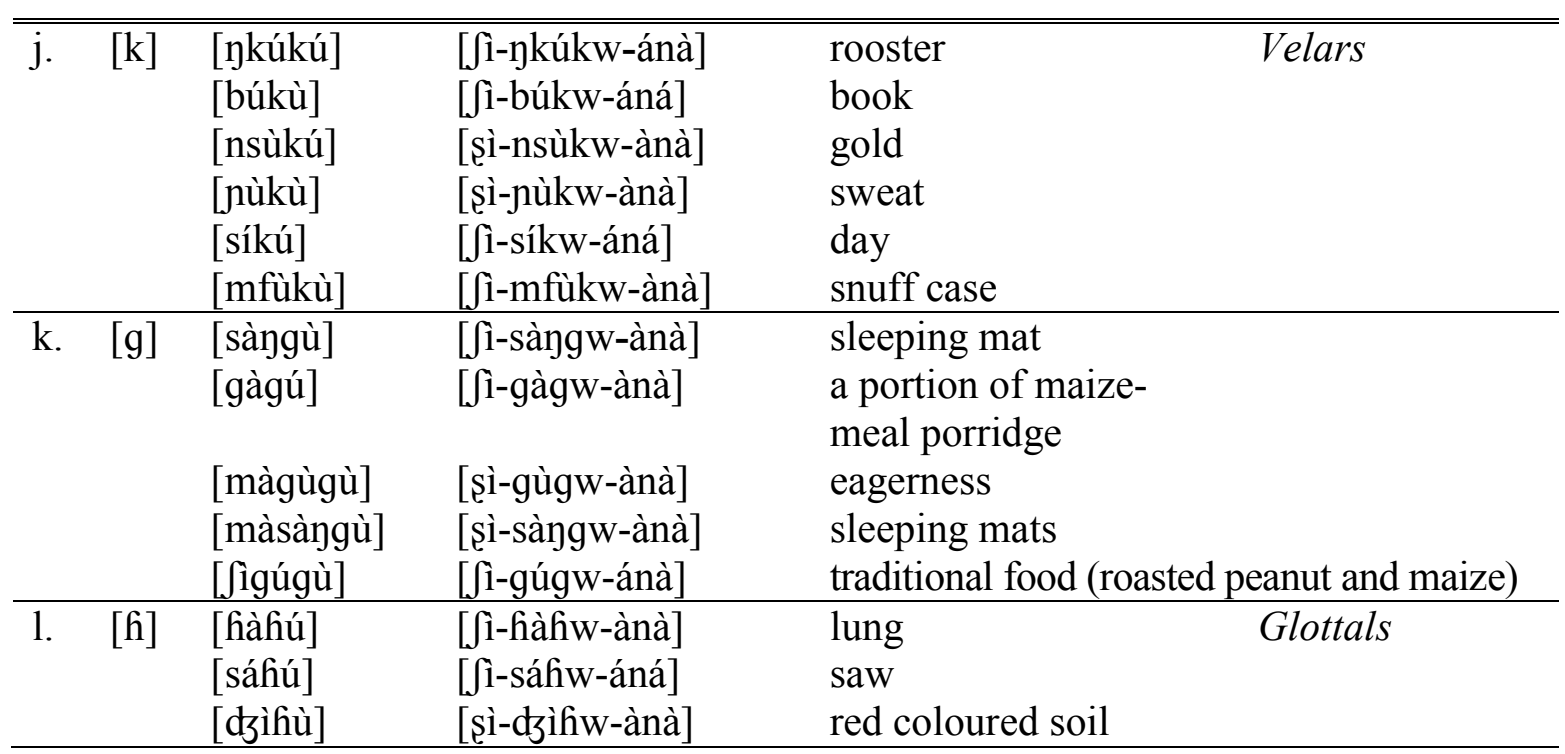

\subsection{Velarisation of the bilabial nasal [m]}

When the root-final round vowels $/ \mathrm{o} /$ and $/ \mathrm{u} /$ are preceded by the bilabial nasal $/ \mathrm{m} /$, the labial corresponds to the velar [y] in the surface form. In (7), the labial nasal is followed by /o/, and in (8) it is followed by $/ \mathrm{u} /$.

(7) Labial nasal $/ \mathrm{m} /+/ \mathrm{o} /$ before the diminutive suffix - ana

\begin{tabular}{|c|c|c|c|}
\hline & Root noun & Diminutive & '(a) small ...' \\
\hline a. & [nòmò] & [كî-nòyw-ànà] & mouth \\
\hline b. & [nsómó] & 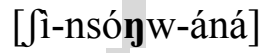 & seam \\
\hline c. & [gòmò] & [ & forehead \\
\hline d. & [fómò] & 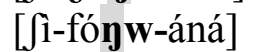 & form \\
\hline e. & [ $\int 1 k^{\text {hómó] }}$ & [ $\int \hat{1}-\mathrm{k}^{\mathrm{h}}$ ónw-áná] & cup handle \\
\hline
\end{tabular}

(8) Labial nasal $/ \mathrm{m} /+/ \mathrm{u} /$ before the diminutive suffix - ana

\begin{tabular}{|c|c|c|c|}
\hline & Root noun & Diminutive & '(a) small ...' \\
\hline a. & [nsímú] & [Jî-nsínw-áná] & field \\
\hline b. & [ṇàmù] & 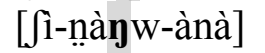 & neck \\
\hline c. & [hòmú] & [ fî-hònw-ánà] & cow \\
\hline d. & [rìsímú] & 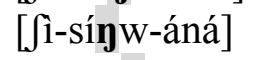 & song \\
\hline e. & [mùmú] & 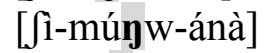 & hot weather \\
\hline f. & [ jîkòmù] & 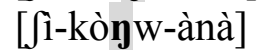 & hoe \\
\hline
\end{tabular}

\subsection{Deletion after the labial continuants [f], [pf], [bv] or [w]}

When root-final round vowels are preceded by the oral labials $(/ \mathrm{f} /, /(\mathrm{m}) \mathrm{pf} /, / \mathrm{bv} / \mathrm{or} / \mathrm{w} /)$, the round vowels delete. The data in this section fills a gap in the previous studies. 
(9) Labial continuants + round vowels before the diminutive suffix -ana

\begin{tabular}{|c|c|c|c|c|}
\hline & Root noun & Diminutive & '(a) small ...' & \\
\hline a. & [sèfò] & 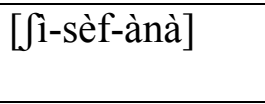 & $\begin{array}{l}\text { sif (Afrikaans for } \\
\text { 'sieve') }\end{array}$ & $/-\mathrm{fo} /$ \\
\hline \multirow[t]{4}{*}{ b. } & [tghéfù] & [sì-ty'éf-ánà] & poison & \multirow[t]{4}{*}{$/-\mathrm{fu} /$} \\
\hline & [háfù] & [ $\int 1$-háf-ánà] & half & \\
\hline & [ Jèlùfù] & 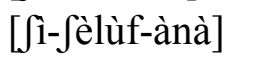 & shelf & \\
\hline & [gòlùfù] & [ $\int \hat{1}$-gòlùf-ànà $]$ & golf & \\
\hline \multirow[t]{4}{*}{ c. } & [lámpfú] & [ & branch used for fences & \multirow[t]{4}{*}{$/{ }^{(m)} \mathrm{pfu} /$} \\
\hline & {$\left[\mathrm{nì}^{\mathrm{m}} \mathrm{pfú}\right]$} & [ $\int 1$-jìm pf-áná] & sheep & \\
\hline & [nóm $\left.{ }^{\mathrm{m}} \mathrm{pfú}\right]$ & 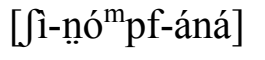 & nose & \\
\hline & [ndlòpfù] & [ $\int 1$-ndlòpf-ànà $]$ & elephant & \\
\hline d. & 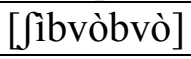 & [ $\int 1$ i-bvòbv-ànà $]$ & dead chicken anus & /-bvo/ \\
\hline e. & 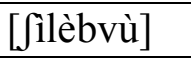 & [ & chin & /-bvu/ \\
\hline \multirow[t]{2}{*}{ f. } & [nàwù] & 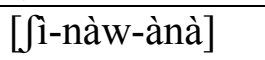 & law & \multirow[t]{2}{*}{ /-wu } \\
\hline & [láwú] & 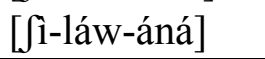 & boy's house & \\
\hline
\end{tabular}

\subsection{Section summary}

The generalisations so far are three-fold. First, in vowel hiatus contexts, round vowels correspond to the labial glide [w] in the surface form. Non-round vowels do not usually have correspondents and simply delete before the diminutive suffix, as in (10a). Second, when the consonant preceding round vowels is an oral labial ([f], [pf], [bv] or [w]), round-vowel deletion takes place; the same pattern is observed in non-round vowels. While this generalisation also applies to other oral labials $\left([\mathrm{p}],[\mathrm{ph}],[\mathrm{b}],\left[{ }^{\mathrm{m}} \mathrm{b}\right],[\beta]\right)$, the former set of oral labials undergoes affrication in addition to vowel deletion (see section 5.1 for further discussion). Third, when the consonant preceding round vowels is $/ \mathrm{m} /$, the round vowels correspond to [w] and the $/ \mathrm{m} /$ corresponds to the velar nasal [n]. Non-round vowels do not have such a correspondent relationship, as illustrated in (10b).

(10) Phonological processes when the root-final vowel is round

a. Changes in the root-final vowel

i. Glide formation

$$
/ \mathrm{u} / \text { or } / \mathrm{o} / \rightarrow[\mathrm{w}] \quad / \ldots \mathrm{C}_{[- \text {labial }]} \_ \text {-ana }
$$

ii. Vowel deletion

$$
/ \mathrm{u} / \text { or } / \mathrm{o} / \quad \rightarrow \varnothing \quad / \ldots \mathrm{C}_{[+ \text {labial,-nasal }]} \_ \text {-ana } \quad \text { (see } \S 5.1 \text { for exceptions) }
$$

b. Changes in the consonant immediately preceding the final vowel

Velarisation

$/ \mathrm{m} / \quad \rightarrow[\mathrm{y}] \quad / \ldots \ldots[\mathrm{w}]-$ ana

These generalisations will be analysed in terms of a rule-based analysis and a constraint-based analysis (OT) in section 4. 


\section{Analysis: Repair strategies in labial dissimilation}

The phonological patterns presented in section 3 show that round vowels become a labial approximant $[\mathrm{w}]$ in the diminutive, as illustrated in (11a). Xitsonga, however, does not allow two adjacent segments with the [labial] feature, and the repair strategies are (i) to velarise the labial nasal [m], as in (11b), or (ii) to delete the labial after the non-nasal labials [f, w, pf, bv], as in (11c).

(11) Glide formation and avoidance of adjacent [labial] segments

\begin{tabular}{|c|c|c|c|c|}
\hline & Root noun & Diminutive & '(a) small ...' & \\
\hline a. & [pótó] & [Jî-pótw-áná] & pot & Glide Formation \\
\hline b. & [nòmò] & 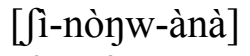 & mouth & Velarisation \\
\hline c. & [sèfò] & [ $\int \hat{1}$-sèf-ànà] & sieve & Deletion \\
\hline
\end{tabular}

\subsection{Rule-based analysis}

The three phonological processes in (10) follow the rule ordering in (12). First, the glideformation rule changes the round vowels $/ \mathrm{u}, \mathrm{o} /$ to $[\mathrm{w}]$. Second, the velarisation rule changes the labial nasal $[\mathrm{m}]$ to the velar $[\mathrm{y}]$ in order to avoid sequences of labial segments $\left(\mathrm{OCP}^{3}\right.$-labial). Third, the deletion rule deletes the root-final labial segment [w] due to the avoidance of two adjacent segments with the labial specification.

(12) Summary of the rule-based analysis

\begin{tabular}{|c|c|c|c|}
\hline /Si-pótó-ana/ & / /1̂-nòmò-ana/ & / /i-sèfò-ana/ & \\
\hline Jipotwana & fìnomwana & Jisefwana & Glide Formation \\
\hline- & Jìnoywana & - & Velarisation \\
\hline- & - & Sisefana & [labial]-Deletion \\
\hline
\end{tabular}

If the deletion rule precedes the velarisation rule, we expect that / fìnomuánà/ will be realised as *[ [inomana $]$ in (13), which is unattested.

Applying [labial]-Deletion before Velarisation
\begin{tabular}{ll}
$/ \int$ i-nomo-ana/ & \\
\hline Jinomwana & Glide Formation \\
Jinomana & [labial]-Deletion \\
- & Velarisation \\
\hline$*[$ jinomana $]$ &
\end{tabular}

If the vowel deletion rule were to be applied first, it bleeds the glide formation rule and the velarisation rule, generating *[Sipotana $]$ and $*[$ [inomana $]$.

In the rule-based analysis, the non-round vowels delete or trigger palatalisation. The non-round front vowels /i/ and /e/ are subject to the glide formation rule, which changes /i/ and /e/ to the palatal glide [j]. Another rule then deletes the palatal glide. In the case of the root-final vowel [a], this vowel simply coalesces with the first vowel of the suffix -ana.

\footnotetext{
${ }^{3}$ The Obligatory Contour Principle (OCP) prohibits two identical features from being adjacent in the surface form.
} 


\subsection{An Optimality Theory (constraint-based) analysis}

The data analysis in this section involved the use of a constraint-based theory, namely Optimality Theory (OT; Prince and Smolensky 1993/2004) as the framework. In this theory, the avoidance of sequences of [labial] segments is posited as a competition between faithfulness constraints (14) and markedness constraints (15).

(14) Faithfulness constraints (cf. McCarthy and Prince 1995)

a. MAX-V[LAB]: Assign a violation mark when a round vowel ([labial]) in the input does not have a correspondent in the output.

b. IDENT(LAB): Assign a violation mark when corresponding segments in the input and the output do not have identical values for the [labial] feature.

c. IDENT(CONS): Assign a violation mark when corresponding segments in the input and the output do not have identical values for the [consonantal] feature.

(15) Markedness constraints

a. OCP-LABIAL: Assign a violation mark to labials that are adjacent. (cf. Myers 1997)

b. *VV: Assign a violation mark to vowels that are adjacent. (cf. Casali 1996)

c. $*[\mathrm{x}]$ : Assign a violation mark to the velar fricative $[\mathrm{x}]$. (Phonotactic constraint)

d. ${ }^{*} \mathrm{Cj}$ : Assign a violation mark to palatalised stops. ${ }^{4}$ (Phonotactic constraint)

The tableau ${ }^{5}$ in (16) shows that the two markedness constraints *VV and MAX-V dominate the IDENT(CONS) constraint. In the optimal candidate in (16a), the root-final round vowel has a correspondent $[\mathrm{w}]$ in the output. Vowel hiatus is repaired by changing the vowel to a glide. The faithful candidate in (16b) violates the *VV constraint. The deletion candidate in (16c) satisfies the *VV constraint, but it violates the MAX-V[LAB] constraint.

(16) Glide Formation: OCP-LABIAL, *VV, MAX-V[LAB], IDENT(LAB) >> IDENT(CONS)

\begin{tabular}{|l|l|l|l:l:l:l|c|}
\hline & & $/$ i-poto-ana/ & OCP-LABIAL & $*$ VV & $\begin{array}{c}\text { MAX-V } \\
{[\mathrm{LAB}]}\end{array}$ & IDENT(LAB) & IDENT(CONS) \\
\hline a. & $*$ & {$[$ jipotwana $]$} & & & & $*$ & L \\
\hline b. & & {$[$ ipotoana $]$} & & $\mathrm{W}^{*}$ & & & $\mathrm{~L}$ \\
\hline c. & & {$[$ [ipotana $]$} & & & $\mathrm{W}^{*}$ & & \\
\hline
\end{tabular}

The ranking when the labial nasal velarises is shown in (17). The faithful candidate in (17b) violates the *VV constraint. In $(17 \mathrm{c})$, the candidate avoids *VV violation by changing the round vowel to a labial glide, but this incurs a violation of OCP-LABIAL (in addition to the violation of IDENT(CONS)). The deletion of the input round vowel violates MAX-V[LAB] in (17d). The

\footnotetext{
${ }^{4}$ One reviewer raised concerns with the constraint $* \mathrm{Cj}$ because a palatalised bilabial plosive $\left[\mathrm{b}^{\mathrm{j}}\right]$ (spelled 'by') and a palatalised alveolar plosive [ $\left.\mathrm{d}^{j}\right]$ (spelled 'dy') are listed in Baumbach (1987). A recent study on the acoustics and articulation of voiced affricates in Xitsonga under discussion by Lee, Kawahara and Takemura (2014) shows that the spelling 'by' is a voiced labial-released alveolar affricate [bz] and the spelling 'dy' is a voiced palatal affricate [d]. We believe that ${ }^{*} \mathrm{Cj}$ is an active constraint in the dialect of Xitsonga discussed in this paper. We do not, however, exclude the possibility that the Xitsonga dialect described in Baumbach (1987) does in fact have a palatalised labial and a palatalised alveolar in the consonant inventory, which would mean that the ${ }^{*} \mathrm{Cj}$ constraint is not undominated.

${ }^{5}$ All tableaux in this paper follow the comparative tableaux format (see Prince 2002).
} 
optimal candidate violates two faithfulness constraints: IDENT(LAB) due to the change of place from $[\mathrm{m}]$ to $[\mathrm{y}]$, and IDENT(CONS) because /o/ corresponds with [w].

(17) Velarisation: OCP-LABIAL, *VV, MAX-V[LAB] >> IDENT(LAB), IDENT(CONS)

\begin{tabular}{|c|c|c|c|c|c|c|c|}
\hline & & / 1 i-nomo-ana/ & OCP-LABIAL & $* \mathrm{VV}$ & $\begin{array}{l}\text { MAX-V } \\
\text { [LAB] }\end{array}$ & IDENT(LAB) & IDENT(CONS) \\
\hline a. & 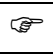 & [Jinonwana] & & & & $*$ & $*$ \\
\hline b. & & [ Jinomoana] & & $\mathrm{W}^{*}$ & & $\mathrm{~L}$ & $\mathrm{~L}$ \\
\hline c. & & [ Sinomwana] & $\mathrm{W}^{*}$ & & 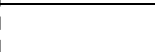 & $\mathrm{L}$ & $*$ \\
\hline d. & & [Sinomana] & & & $\mathrm{W}^{*}$ & $\mathrm{~L}$ & $\mathrm{~L}$ \\
\hline
\end{tabular}

In the deletion cases, the faithful candidate in $(18 b)$ violates the $* V V$ constraint. Changing the underlying / $\mathrm{f} /$ to the velar fricative $[\mathrm{x}]$, as in $(18 \mathrm{c})$, violates the constraint $*[\mathrm{x}]$ which is motivated by the phonotactic ban on this sound in Xitsonga. The glide formation candidate in (18d) violates the higher-ranked OCP-LABIAL constraint. The optimal candidate in (18a) violates the MAX-V[LAB] constraint because the input /o/ does not have a correspondent in the output, but it satisfies other markedness constraints that are ranked higher.

(18) Deletion

\begin{tabular}{|l|l|l|c:c:c|c|c|c|}
\hline & & $/$ ji-sefo-ana/ & OCP-LABIAL & $*[\mathrm{x}]$ & $* \mathrm{VV}$ & $\begin{array}{c}\text { MAX-V } \\
{[\mathrm{LAB}]}\end{array}$ & IDENT(LAB) & IDENT(CONS) \\
\hline a. & {$[$ [isefana $]$} & & & & $*$ & & \\
\hline b. & {$[$ [isefoana $]$} & & & $\mathrm{W} *$ & $\mathrm{~L}$ & & \\
\hline c. & {$[$ [isexwana $]$} & & $\mathrm{W} *$ & & $\mathrm{~L}$ & $\mathrm{~W} *$ & $\mathrm{~W} *$ \\
\hline d. & & {$[$ [isefwana $]$} & $\mathrm{W} *$ & & & $\mathrm{~L}$ & & $\mathrm{~W} *$ \\
\hline
\end{tabular}

Unrounded vowels are deleted in vowel hiatus contexts. The tableau in (19) shows that the faithful candidate violates *VV in (19b). In (19c), the non-round vowel /i/ corresponds to the glide [j]. This candidate is ruled out by the co-occurrence restriction constraint $* \mathrm{Cj}$. The optimal candidate satisfies the higher ranked constraints.

(19) Deletion of non-round vowels

\begin{tabular}{|l|l|l|l:l:l|c|c|c|}
\hline & & $\begin{array}{c}\text { / } \mathrm{i} \text {-mali-ana/ } \\
\text { a. }\end{array}$ & OCP-LABIAL & $* \mathrm{Cj}$ & $* \mathrm{VV}$ & $\begin{array}{c}\text { MAX-V } \\
{[\mathrm{LAB}]}\end{array}$ & IDENT(LAB) & IDENT(CONS) \\
\hline b. & {$[$ Jimalana $]$} & & {$[$ imaliana $]$} & & & $*$ & & \\
\hline c. & & {$[$ Jimaljana $]$} & & $\mathrm{W} *$ & $\mathrm{~W} *$ & $\mathrm{~L}$ & & \\
\hline
\end{tabular}

So far, we have proposed two analyses of Xitsonga diminutive formation: in (i) a rule-based theory and in (ii) a constraint-based theory (OT). While both analyses can account for the surface patterns in Xitsonga diminutives, an OT analysis provides a clear reason why these processes occur - as an avoidance measure against two labials or two vowels in the surface form.

When the final round vowel is preceded by the three labial obstruents $\left[\mathrm{p},{ }^{\mathrm{m}} \mathrm{b}, \beta\right]$, affrication is employed. This is another type of repair strategy that will be discussed in the following section. 


\section{Affrication as a repair strategy?}

When the consonant preceding a round vowel is one of the oral labials $\left[\mathrm{p},{ }^{\mathrm{m}} \mathrm{b}, \beta\right]$ or when a liquid $[1, \underline{r}]$ precedes a non-round vowel, the vowels are deleted and the consonant corresponds to the voiced affricate in the diminutive, as in (20).

(20) Mapping to affricates

a. round vowels after a labial (Vowel Deletion, Affrication: more data below)

[nàmbù] [ [ î̀-nàmbz-ànà] 'a small river'

b. non-round vowels after a liquid (Vowel Deletion, Affrication)

\begin{tabular}{|c|c|c|}
\hline [mùrúí] & [ $\int 1$-mùdz-ánà] & 'a small tree' \\
\hline [ykèlé] & [ $\int 1$-nkédz-ánà] & 'a small narrow hole' \\
\hline [màfúrá] & [sì-fúdz-ánà] & 'little fat' \\
\hline
\end{tabular}

In previous studies (cf. Baumbach 1987, Ziervogel 1967 and Burheni 2012), the sound change of round vowels after labial obstruents was characterised as "Palatalisation". A closer examination shows that the change is to an alveolar affricate instead of a palatal affricate. In this paper, we will call this rule simply "Affrication", as in (21). This rule maps the root consonants before the final vowel to an affricate.

$$
\begin{aligned}
& \text { Affrication } \\
& / 1 / \text { or } / \mathrm{r} / \mathrm{l} \quad \rightarrow[\mathrm{dz}] \quad / \ldots{ }_{-} \text {-ana } \\
& / \mathrm{p} /, / \mathrm{m} \mathrm{b} / \text { or } / \mathrm{b} / \rightarrow[\mathrm{pz}],[\mathrm{bz}] / \ldots \text {-ana }^{-}
\end{aligned}
$$

This type of affrication has been reported in passivisation in languages such as isizulu. In Xitsonga, however, affrication does not occur in passivisation, in which the suffix [-iw] is added to the verbal stem, without triggering a phonological process.

\subsection{Affrication after labial obstruents: $[p],\left[{ }^{(m)} b\right],[\beta]$}

Data is shown in (22) and (23) where the round vowels /o/ and /u/ are preceded by the three

\begin{tabular}{|c|c|c|c|}
\hline & Root noun & Diminutive & '(a) small ...' \\
\hline a. $[\mathrm{p}]$ & [sópò] & [sì-sópz-áná] & soup \\
\hline \multirow[t]{2}{*}{ b. $\quad\left[{ }^{\mathrm{m}} \mathrm{b}\right]$} & [mòmbó] & 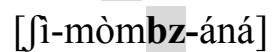 & face \\
\hline & [k ómbó] & [ $\int \hat{i}-\mathrm{k}^{\mathrm{h}}$ ómbz-áná] & misfortune \\
\hline \multirow[t]{5}{*}{ c. $[\beta]$} & [húßó] & 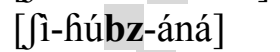 & gathering place \\
\hline & {$\left[\mathrm{yk}^{\mathrm{h}} \mathrm{u} \beta \mathrm{o}\right]$} & [ $\int \hat{1}-\eta k^{\mathrm{h}}$ ùbz-ànà] & feast \\
\hline & [dzóßó] & 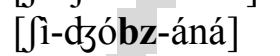 & animal skin \\
\hline & [màkòßó] & [șì-kòbz-áná] & eyes that are deep-set \\
\hline & [ndzòßò] & [ î-ndzòbz-ànà] & animal skin cloth \\
\hline
\end{tabular}
labial obstruents $\left.[\mathrm{p}],{ }^{(\mathrm{m})} \mathrm{b}\right]$ and $[\beta]$.

(22) Labial stops $+/ \mathrm{o} /$ before the diminutive suffix - ana 
(23) Labial stops $+/ \mathrm{u} /$ before the diminutive suffix -ana

\begin{tabular}{|c|c|c|c|}
\hline & Root noun & Diminutive & '(a) small ...' \\
\hline \multirow[t]{4}{*}{$\begin{array}{ll}\text { a. } & {[\mathrm{p}]}\end{array}$} & [mùkápù] & [sì-kápz-ánà] & soft porridge \\
\hline & [súpù] & [sì-súpz-ánà] & soup \\
\hline & [kùnúpù] & [ אî-kùnúpz-ánà] & button \\
\hline & [ntsúpú] & [ & totem \\
\hline b. $[\mathrm{b}]$ & [Jîgúbù] & [ $\int$ i-gùbz-ánà] & musical bow \\
\hline c. $\left[\mathrm{p}^{\mathrm{h}}\right]$ & [phúphó & [ $\int \hat{i}-p^{h}$ úpz-ànà $]$ & pillar \\
\hline d. $\quad\left[{ }^{\mathrm{m}} \mathrm{b}\right]$ & [nàmbù] & [ î̀-nàmbz-ànà] & river \\
\hline & [rùmbù] & [ î̀nùmbz-ànà] & intestine \\
\hline & [dzàmbù] & [ & sun \\
\hline & [ $\left.\mathrm{t}^{\mathrm{h}} \mathrm{ùmbù}\right]$ & [ $\mathrm{j}^{\mathrm{i}} \mathrm{t} \mathrm{h}$ ùmbz-ànà $]$ & rubber tube \\
\hline & [ntàmbù] & [ & rope \\
\hline e. $[\beta]$ & [ygù $\beta u ̀]$ & [ [jîngùbz-ànà] & blanket \\
\hline
\end{tabular}

Unlike the other repair strategies presented in section 3, affrication occasionally occurs when these labial obstruents precede non-round vowels. In each group in (24), the (letter-1) examples show examples with affrication. The more common pattern is that the non-round vowels delete, as shown in the (letter-2) examples.

(24) Affrication in roots with final non-round vowels

\begin{tabular}{|c|c|c|c|}
\hline & Root noun & Diminutive & '(a) small ...' \\
\hline $\begin{array}{ll}\mathrm{a}-1 . & {[\mathrm{mb}]}\end{array}$ & [kwémbé] & [ 11-kwémbz-ánà] & pumpkin \\
\hline \multirow[t]{3}{*}{$\mathrm{a}-2 . \quad b u t$} & [ṃèlèmbè] & 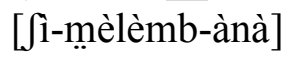 & rhino \\
\hline & [hémbè] & 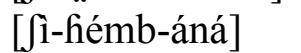 & shirts \\
\hline & [jémbé] & [ [̂1-jémb-áná] & wild fruit \\
\hline $\mathrm{b}-1 . \quad[\beta \mathrm{a}]$ & [ntshà $\beta a ̀]$ & [ $\int 1$ ints àbz-ànà $]$ & mountain \\
\hline \multirow[t]{3}{*}{$\mathrm{b}-2$} & [mìsáßá] & [sì-sà $\beta$-ànà] & soil \\
\hline & [tùßà] & [ î-tù $\beta$-ànà] & dove \\
\hline & [gòßà] & [ $\int 1$-gò $\beta$-ànà $]$ & deep valley \\
\hline \multirow[t]{3}{*}{$\mathrm{c}-1$. } & [ndlé $\beta e ́]$ & [ ĵi-ndlébz-ánà] & ear \\
\hline & [ngùlùßè] & [ [̂1-ngùlùbz-ànà] & pig \\
\hline & [tîhòßè] & [sì-hòbz-ànà] & traditional meal \\
\hline c-2. but & [nsè $\beta \mathrm{è}]$ & [ $\int 1$-nsè $\beta$-ànà] & arrow \\
\hline \multirow[t]{2}{*}{$\mathrm{d}-1 . \quad[\beta \mathrm{i}]$} & [yk á $\beta \dot{1}]$ & 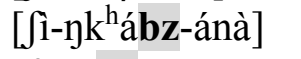 & lash \\
\hline & [ráßí] & [ [̂i-rábz-ánà] & branch \\
\hline d-2. but & [k $\left.\mathrm{k}^{\mathrm{h} u ́ \beta i ́}\right]$ & [sì-k ${ }^{h}$ ú $\beta$-ánà] & foam \\
\hline
\end{tabular}

The examples in (25) show that affrication may not occur even when the phonological environments are met. Here, the round vowels are preceded by labial obstruents but these vowels are deleted.

(25) Round vowels not undergoing affrication

\begin{tabular}{|c|c|c|c|}
\hline & Root noun & Diminutive & '(a) small ...' \\
\hline a. $[-\beta o]$ & [mḅòßó] & [Jî-mbò $\beta$-ánà] & small hole \\
\hline b. $[-p u]$ & [k h́pù $]$ & [ $\int \mathrm{i}-\mathrm{k}^{\mathrm{h}}$ áp-ánà $]$ & cup (English) \\
\hline
\end{tabular}


The variation involving affrication in diminutive construction does not have a simple explanation. A detailed study of this phenomenon is left for future studies as it is beyond the scope of the current paper.

\subsection{The motivation behind affrication as a repair strategy of labial dissimilation}

The data in section 5.1 suggests that the process of affrication is not as uniform as the other processes described in section 3. In this section, instead of developing a formal analysis of the affrication process, we will present a short discussion thereof, drawing from cross-linguistic comparisons.

An analogous affrication pattern is attested in isiZulu. Labial consonants in the root alternate with palatal consonants in the diminutive construction (Doke 1926:127 in Bennett 2013:335). Both in isiZulu and in Xitsonga, the last consonant of the root changes to a palatal affricate. In isiZulu, this phenomenon is also found in the passive construction, while in Xitsonga the passive does not show affrication.

Affrication in isiZulu diminutives

\begin{tabular}{|c|c|c|c|}
\hline & Root noun & Diminutive & '(a) small ...' \\
\hline a. $[\mathrm{mb}]$ & [isi-vimbo] & [isi-vindzana] & stopper \\
\hline b. $\quad[\mathrm{p}]$ & [im-pup $\left.{ }^{\mathrm{h}} \mathrm{u}\right]$ & [i-mpufana] & meal \\
\hline
\end{tabular}

An analysis of such palatalisation is proposed in Kotzé and Zerbian (2008). In discussing palatalisation in the Sotho languages, they argue that this process is triggered either by an overt palatal glide or by a palatal glide that emerges as a result of two phonological processes, namely glide formation and labial dissimilation. The labial glide [w] changes into the palatal glide [j] after a labial sound due to labial dissimilation in Northern Sotho. This derived palatal glide [j] triggers palatalisation, as in (27a). This analysis, however, does not address the change of [j] into [w] after the palatal sound in the surface form, as in (27b).

Palatalisation in Northern Sotho (Kotzé and Zerbian 2008) ${ }^{6}$

\begin{tabular}{lll} 
a. $/$ *kobo-ana/ & b. $/ *_{\text {setopo-ana/ }}$ & \\
\hline *kobwana & *setopwana $^{\text {*kobjana }}$ & Glide Formation \\
*kobjana & *setopjana & Labial Dissimilation \\
\hline [kobzana] & [setotswana] & (Palatalisation)
\end{tabular}

From a diachronic perspective, Ohala (1981:188) reports a change that occurred from ProtoBantu to Shona, in which the round vowel *u became the labial glide *w, which in turn became a velar affricate.

(28) A diachronic change in Shona (a dissimilation process)

\begin{tabular}{lllll} 
& Proto-Bantu & \multicolumn{1}{c}{ Pre-Shona } & \multicolumn{1}{c}{ Shona } & \\
\hline a. & $*$-bua- & >*bwa & $>$-bya & 'dog' \\
b. & $*$-mu- & $>$ *kumwa & $>$-kumya & 'to drink'
\end{tabular}

\footnotetext{
${ }^{6}$ Note that the representation here uses IPA symbols, whereas Kotzé and Zerbian (2008) use the orthography.
} 
In Xitsonga, it is possible to surmise that such diachronic change has occurred, where affrication would have occurred after the frication process.

Two theories can possibly account for this process. First, the Perceptual Cues theory, proposed in Ohala (1981) and Steriade (2009), would argue that affrication in Xitsonga or palatalisation in isiZulu as a repair strategy in labial dissimilation is perceptually driven. Second, the Consonant Mutation theory, reported in other Bantu languages as well, would argue that a mutation to an affricate is due to historical super high vowels (Zoll 1996). The super high vowels would have changed to an affricate at some point in the language's history.

The confounding factors regarding affrication are, firstly, that Xitsonga also has affrication where the liquid consonants themselves change to an affricate, as in (29). This type of affrication might also be triggered by a type of dissimilation. Secondly, the affrication of liquids behaves similarly to isiZulu palatalisation or Bantu consonant mutation because the root consonant itself changes to an affricate and the root-final vowel is deleted.

$$
\begin{aligned}
& \text { Affrication of } / 1 / \text { and } / \mathrm{r} / \\
& \text { [mùníi } \quad \text { [ } \mathrm{i} \text {-mùct-ánà] 'a small tree' }
\end{aligned}
$$

\section{Conclusion}

In this paper, we have shown that disjointed phonological processes can be understood as closely related repair strategies driven by OCP-LABIAL. A response to vowel hiatus by round vowels is that they correspond to a labial glide $(/ \mathrm{o} /$ or $/ \mathrm{u} / \rightarrow[\mathrm{w}])$. When these round vowels are immediately preceded by labial consonants, two repair strategies occur in response to labial dissimilation: either the labial nasal $/ \mathrm{m} /$ corresponds to the velar nasal [ $\mathrm{y}]$ or the round vowels delete after [f, pf, bv, w].

Round vowels occasionally correspond to an affricate. This pattern may be a repair strategy for labial dissimilation, but there are many exceptions. More research is needed to understand the exact nature of the affrication process from a diachronic as well as a phonetic perspective.

\section{Acknowledgements}

We thank two anonymous reviewers for the helpful comments. We also thank Jeremy Perkins, William Bennett and the audience of SAMWOP 2 for earlier comments.

\section{References}

Baumbach, E.J.M. 1987. Analytical Tsonga grammar. Pretoria: University of South Africa.

Bennett, Wm.G. 2013. Dissimilation, Consonant Harmony, and Surface Correspondence. PhD dissertation, Rutgers University.

Burheni, C. 2012. An Analysis of Sound Changes in Diminutive Nouns of Xitsonga. Honours thesis, University of Venda. 
Casali, R. 1996. Vowel elision in hiatus contexts. UCLA Working Papers in Linguistics 1: 18-56. Cuenod, R. 1967. Tsonga-English dictionary. Braamfontein: Sasavona Books.

Doke, C.M. 1926. The phonetics of the Zulu language. Johannesburg: Witwatersrand University Press.

Kotzé, A.E. and S. Zerbian. 2008. On the trigger of palatalization in the Sotho languages. Journal of African Languages and Linguistics 29(1): 1-28.

Lee, S.J. 2009. H tone, depressors and downstep in Tsonga. In M. Matondo, F. McLaughlin and E. Potsdam (eds.) Selected proceedings of the $38^{\text {th }}$ Annual Conference on African Linguistics: Linguistic Theory and African Language Documentation. Somerville, MA: Cascadilla Proceedings Project. pp. 26-37.

Lee, S.J., S. Kawahara and A. Takemura. 2014. The articulation and acoustics of voiced affricates in Xitsonga. Paper presented at the joint LSSA/SAALA/SAALT "Language: Synergies and Intersections" Conference. 24-27 June 2014, University of the Witwatersrand, Johannesburg.

McCarthy, J.J. and A. Prince. 1995. Faithfulness and reduplicative identity. In J. Beckman, L.W. Dickey and S. Urbanczyk (eds.) University of Massachusetts occasional papers in linguistics 18. Amherst, MA: GLSA Publications. pp. 249-384.

Myers, S. 1997. OCP effects in optimality theory. Natural Language \& Linguistic Theory 15(4): 847-892.

Ohala, J.J. 1981. The listener as a source of sound change. In C.S. Masek, R.A. Hendrik and M.F. Miller (eds.) CLS 17: Papers from the parasession on language and behavior. Chicago: Chicago Linguistic Society. pp. 178-203.

Prince, A. 2002. Arguing Optimality. In A. Coetzee, A. Carpenter and P. de Lacy (eds.) University of Massachusetts occasional papers in linguistics 26: Papers in Optimality Theory II. Amherst, MA: GLSA Publications. pp. 269-304.

Prince, A. and P. Smolensky. 1993/2004. Optimality Theory: Constraint interaction in Generative Grammar. Cambridge, MA: MIT Press.

Steriade, D. 2009. The phonology of perceptibility effects: The P-map and its consequences for constraint organization. In K. Hanson and S. Inkelas (eds.) The nature of the word: Studies in honor of Paul Kiparsky. Cambridge, MA: MIT Press. pp. 151-179.

Ziervogel, D. 1967. Handboek vir die spraaklanke en klankveranderinge in die Bantoetale van Suid-Afrika. Pretoria: Universiteit van Suid-Afrika.

Zoll, C. 1996. Parsing Below the Segment in a Constraint Based Framework. PhD dissertation, University of California. 